\title{
Soil Biological Activity in Relation to Organic and Bio-fertilizer Application
}

\author{
M.A.Youssef ${ }^{*}$, A. I. El-Desoky ${ }^{*}$ and Azza R. Ahmed ${ }^{* *}$ \\ "Soils and Water Science Department, Faculty of Agriculture, \\ AL-Azhar University, Assiut and ${ }^{* *}$ Soils, Water and \\ Environment Institute, Research Center, Giza, Egypt.
}

\begin{abstract}
A INCUBATION experiment was conducted into Laboratory of Soils and Water Sci. Dept., Fac. of Agric., AL-Azhar Univ., Assiut, Egypt. The aim is to study the effect of organic materials (filter mud cake, sheep and chicken manures) and bio-fertilizer (effective microorganism's, EM) on the soil biological activity indicated by $\mathrm{CO}_{2}$-evolution. The experiment was set in a complete randomization design with four replicates.
\end{abstract}

The results indicated that the combination of organic materials and EM gave maximum rate of cumulative $\mathrm{CO}_{2}-\mathrm{C}$ released under chicken manure with EM treatment. Also, it enhanced the $\mathrm{CO}_{2}-\mathrm{C}$ fluxes process during the incubation time particularly at 3 and 7 days (13.14 and $12.22 \mathrm{mg} \mathrm{C} / 100 \mathrm{~g}$ soil, respectively) where fluxes peak appeared. $\mathrm{CO}_{2}-\mathrm{C}$ fluxes differed among treatments according to the descending order; Chicken manure $+\mathrm{EM}>$ sheep manure $+\mathrm{EM}>$ filter mud + $\mathrm{EM}>$ chemical fertilizer $+\mathrm{EM}>\mathrm{EM}$ only.

At full incubation time (127 days), the individual treatment of organic materials with EM decreased soil OM content less to $0.50 \%$.

Keywords: Organic materials, Bio-fertilizer, Soil biological activity and $\mathrm{CO}_{2}$-evolution.

Chemical fertilizers application at extremely high rates for long periods, decrease the potential activity of micro-flora and soil organic matter stability. Organic materials, particularly solid manures, add useful amounts of organic matter to soils, acts as soil conditioners and structural improvers. Also, they increase soil water holding capacity. Drought resistance, structural stability of soil and soils biological activity can be increased.

Mervat et al. (1995) reported that the addition of organic manure (farmyard manure and poultry manure) improved soil biological properties by increasing micro-organisms populations and their activities. In a greenhouse experiment, Abou El-Naga et al. (1996) found that the peak values of the biological activity were detected at 19-29 and 27-49 days after farmyard manure (FYM) application for furrow and drip irrigation method, respectively. Also, soil biological quality indicator, such as biomass $\mathrm{C}$ and $\mathrm{N}$ were improved by compost applications 
(Horwath et al., 2002). Gregory and Vickers (2003) showed that a composted woody organic amendment increased soil organic matter, microbial biomass and $\mathrm{CO}_{2}$ soil respiration rate, especially at higher application rates.

Effective microorganisms (EM) plus Bokashi (organic manure) had the highest microbial densities through either a stimulation of soil micro-flora, or input of compost micro-flora or a combination of both. It is known that nitrogen from organic manures is slowly released, since $25-50 \%$ of it is released in the first year. While $\mathrm{N}$ recovery from organic manure is slightly better than that from fertilizers as $\mathrm{CO}_{2}$ released by decomposition improves availability from soil (Gopalakrishnan, 2007).

Okur et al. (2008) found higher values of soil organic carbon and soil respiration under 25\% FYM with $75 \%$ water holding capacity (WHC) and $100 \%$ WHC treatments than that of the control. The microbial biomass $\mathrm{C}$ level in the soil increased responding to all compost treatments. Also, Araújo et al. (2009) showed that soil microbial activity and biomass were significantly greater in organic agricultural system compared to conventional system.

Bhaskaran and Krishna (2009) showed that the increased level of organic carbon is a good indication of better carbon sequestration in soil by reducing the amount of $\mathrm{CO}_{2}$ released to the atmosphere Branzini et al. (2009) showed that at the end of the incubation period, the total activity of microorganisms was significantly increased by the application of organic amendments and a negative relationship was observed between salinity and $\mathrm{CO}_{2}-\mathrm{C}$.

Fatunbi and Ncube (2009) found that the evolution of $\mathrm{CO}_{2}$ was significantly higher with the application of Lawn clippings and Kraal manure compared to the commercial compost. Combined application of EM with organic materials led to a $24 \%$ higher in $\mathrm{CO}_{2}$ emission after 56 days of incubation compared to EM application only.

\section{Material and Methods}

The current work carried out into Laboratory of Soils and Water Sci. Dept., Faculty of Agriculture, AL-Azhar University, Assiut, Egypt. The present investigation aimed to study the effect of organic materials (filter mud cake, sheep and chicken manures) and bio-fertilizer (EM) on the soil biological activity through incubation technique.

The used soil sample was taken from The Experimental Farm of Fac. of Agric., AL-Azhar Univ., Assiut, Egypt. The organic materials were collected from different sources; Effective microorganisms (EM) from ministry of environment. Sheep and chicken manure (SM \& CM) from the animal production farm, Fac. of Agric., AL-Azhar Univ., Assiut and filter mud cake (FMC) from Abu-Korkas sugar factory, El-Minia, Egypt.

Egypt. J. Soil Sci. 54, No. 1 (2014) 
Some physical and chemical properties of the used soil sample and organic manures were determined according to Jackson (1973) and Page et al. (1982) as presented in Tables 1 and 2.

TABLE 1. Some physical and chemical analyses of the soil.

\begin{tabular}{|c|c|cc|}
\hline \multicolumn{2}{|c|}{ Physical analysis } & \multicolumn{2}{c|}{ Chemical analysis } \\
\hline Bulk density $\left(\mathrm{g} / \mathrm{cm}^{3}\right)$ & 1.47 & Total-P (\%) & 0.06 \\
Saturation percent (SP) & 49.50 & Total-N (\%) & 0.12 \\
Field capacity \% & 24.25 & Total-K (\%) & 0.08 \\
\cline { 1 - 1 } Particle size distribution \%. & Ava.-P (ppm) & 10.50 \\
Sand & 53.60 & Exch.-K (ppm) & 105.21 \\
Silt & 22.20 & O.M (\%) & 1.59 \\
Clay & 24.20 & pH (1:2.5 Susp.) & 0.92 \\
Texture grade & & $\mathrm{CaCO}_{3}(\%)$ & 7.61 \\
Sandy clay loam (SCL) & & & \\
\hline
\end{tabular}

TABLE 2. Chemical analysis of filters mud cake, sheep and chicken manures.

\begin{tabular}{|lccc|}
\hline \multicolumn{1}{|c}{ Characteristics } & $\begin{array}{c}\text { Filter mud } \\
\text { cake }\end{array}$ & Sheep manure & $\begin{array}{c}\text { Chicken } \\
\text { manure }\end{array}$ \\
\hline \hline Total-N \% & 2.05 & 2.10 & 3.20 \\
Total-P \% & 1.49 & 1.31 & 2.81 \\
Total-K \% & 0.95 & 3.86 & 3.01 \\
\hline \hline Organic matter & 31.60 & 39.50 & 56.41 \\
Organic-C & 18.33 & 22.91 & 32.72 \\
pH (1:5 susp.) & 7.61 & 8.33 & 7.13 \\
EC dSm ${ }^{-1}(1: 5$ extract) & 1.050 & 5.060 & 3.580 \\
C/N & 8.9 & 11 & 10 \\
\hline
\end{tabular}

Samples of $100 \mathrm{~g}$ soil were placed into $350-\mathrm{ml}$ glass bottles. The tested organic materials were applied to the soil at a rate equal of $0.20,0.19$ and $0.13 \%$ for filter mud cake, sheep and chicken manure (70 unit of nitrogen as a recommended dose for wheat).

Stock solution of effective microorganism (EM) was diluted by $49.50 \mathrm{ml}$ distilled water that required to saturate the used amount of soil $(\mathrm{SP}=49.50)$. The diluted solution was added to the soil samples and mixed well. Organic material (filter mud cake, sheep and chicken manure) were investigated with and without EM application in addition to control without any fertilizer, mineral fertilizer (nitrate ammonium) and EM treatments as follows: 
$\mathrm{T}_{1}$ - Control (without any Fert.).

$\mathrm{T}_{3}$ - Filter mud cake.

$\mathrm{T}_{5}$ - Sheep manure.

$\mathrm{T}_{7}$ - Chemical fertilizer + EM.

$\mathrm{T}_{9}$ - Chicken manure $+\mathrm{EM}$.
$\mathrm{T}_{2}$ - Chemical fertilizer.

$\mathrm{T}_{4}$ - Chicken manure.

$\mathrm{T}_{6}-\mathrm{EM}$.

$\mathrm{T}_{8}$ - Filter mud cake $+\mathrm{EM}$

$\mathrm{T}_{10}$ - Sheep manure $+\mathrm{EM}$.

The experiment was set in a complete randomized design with four replicates. The filled glass bottles were anaerobically incubated in almost controlled conditions (temperature at $30 \pm 1^{\circ} \mathrm{C}$, moisture at $60 \%$ of the soil field capacity by occasional supplementary application of water) and kept in these conditions for 127 days ( total incubation time).

The treatment mixtures were placed in Kilter glass bottles, with a beaker containing $50 \mathrm{ml}$ of 0.5 normal sodium hydroxyl $(\mathrm{NaOH})$ placed in the middle of the glass bottles to trap the evolved $\mathrm{CO}_{2}$. The glass bottles were sealed air-tight and incubated at $30^{\circ} \mathrm{C}$ for 127 days.

The beakers with $0.5 \mathrm{~N}$ sodium hydroxyl $(\mathrm{NaOH})$ were retrieved daily at 0.0 , $0.125,1.0,2.0,4.0,8.0,16.0,32.0,64.0$ and 127.0 days. At each retrieval time, the glass bottles were left open up to one hour to prevent the development of anaerobic condition. The amount of $\mathrm{CO}_{2}-\mathrm{C}$ trapped was determined by back titration according to Page et al. (1982).

The net $\mathrm{CO}_{2}-\mathrm{C}$ was calculated by subtracting the value of the control from that of the treatments, using the relationship of Anderson (1985).

Where:

$$
\mathrm{CO}_{2}=(\mathrm{B}-\mathrm{V}) \mathrm{NE}
$$

$\mathrm{B}=$ Volume of $\mathrm{HCl}$ used to neutralize $\mathrm{NaOH}$ in the beaker to the end point of the control.

$\mathrm{V}=$ Volume of acid used to neutralize $\mathrm{NaOH}$ in the beaker to the end point.

$\mathrm{N}=$ Normality of the acid.

$\mathrm{E}=$ Equivalent weight (to express data as $\mathrm{C}, \mathrm{E}=6$, while as $\mathrm{CO}=\mathrm{E}=22$ ).

By the end of incubation experiment, soil sample from each treatment was collected, air-dried, sieved through $2 \mathrm{~mm}$ sieve then kept for organic matter determination.

\section{Results and Discussion}

\section{Effect of organic materials on the cumulative $\mathrm{CO}_{2}$-C production}

The cumulative $\mathrm{CO}_{2}-\mathrm{C}$ released from total $\mathrm{C}$ added to soil by the organic materials treatments are shown in Fig. 1. Data clearly indicated that the total cumulative $\mathrm{CO}_{2}-\mathrm{C}$ released were obviously affected by organic materials through incubation time. Generally, at the end of incubation time (127 days), the application of organic materials increased the cumulative amount of $\mathrm{CO}_{2}-\mathrm{C}$ released. 


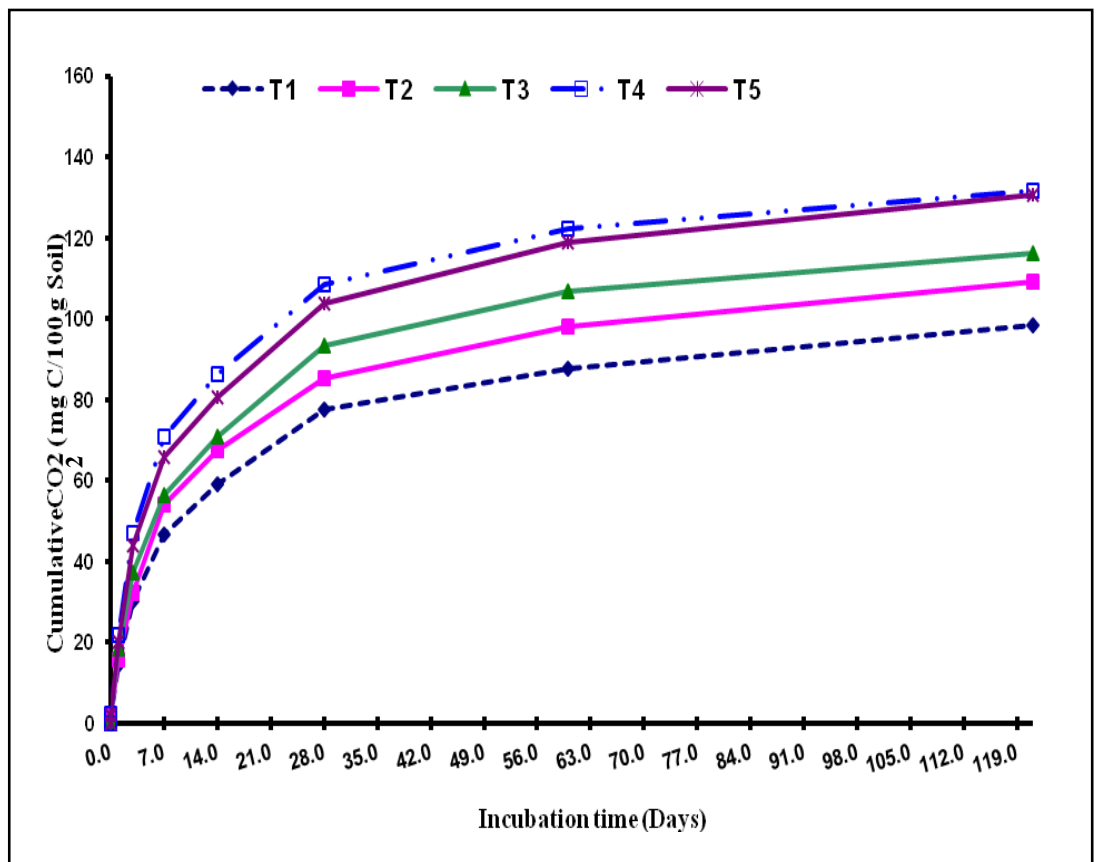

Fig. 1. Cumulative $\mathrm{CO}_{2}-\mathrm{C}$ released as affected by organic materials application through incubation time.

Data showed that the organic manures additions increased the rate of $\mathrm{CO}_{2}-\mathrm{C}$

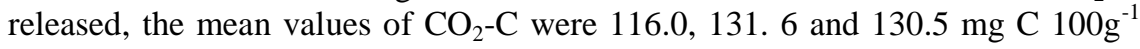
soil after 127 days for filter mud, chicken and sheep manures treatments, respectively. The amount of $\mathrm{CO}_{2}-\mathrm{C}$ released reflects the enhancement of soil biological activity.

Also, data reflected that the lowest amounts of $\mathrm{CO}_{2}-\mathrm{C}$ released were realized in filter mud treatment. This value $\left(116 \mathrm{mg} \mathrm{C} 100 \mathrm{~g}^{-1}\right)$ was probably due to the sharp decline in readily decomposable organic matter and may by attributed to the lowest amount of organic matter in filter mud contents (Table 2).

Also, data indicated that the maximum rate of cumulative $\mathrm{CO}_{2}-\mathrm{C}$ released was obtained under chicken manure treatment. The higher soil respiration indicated a high soil microbial activity due to the permanent and continuous addition of organic matter to the soil and the consequent stimulation of microorganisms.

Generally, higher $\mathrm{CO}_{2}-\mathrm{C}$ released in the soil treated by organic materials, is an indicative of high biological activity, suggesting rapid decomposition of organic residues. 
These results are in accordance with Dumale et al. (2008) who observed that chicken manure application increased significantly $\mathrm{CO}_{2}$ evolution rate and cumulative $\mathrm{CO}_{2}$ evolution in both $0-5$ and $5-20 \mathrm{~cm}$ soil layers. The $\mathrm{CO}_{2}$ evolution were increased by application of chicken manure compared to chemical fertilizer application. In similar instance These results were in agreement with those obtained by Abdel Aal et al. (2002), Horwath et al. (2002), Gregory \& Vickers (2003), Hanna et al. (2005) and Branzini et al. (2009).

Also, Araujo et al. (2009) observed that soil microbial activity and biomass was significantly high in organic management compared to native vegetation.

- Effect of organic materials with EM on the cumulative $\mathrm{CO}_{2}$-C evolution

Data in Fig. 2 clearly indicated that cumulative $\mathrm{CO}_{2}-\mathrm{C}$ released from soil treated by organic materials with Effective Microorganisms (EM) were obviously affected through incubation time. The organic materials with EM additions increased the rate of $\mathrm{CO}_{2}-\mathrm{C}$ production during incubation time.

Generally after 121 of incubation day, the cumulative amount of $\mathrm{CO}_{2}-\mathrm{C}$ released increased by application of organic materials with EM. While treatment of EM only gave the lowest $\mathrm{CO}_{2}-\mathrm{C}$ evolution (98.3) indicating a reduction in soil microbial activity.

The mean values of $\mathrm{CO}_{2}-\mathrm{C}$ released were $117.2,136.5$ and $135.2 \mathrm{mg} \mathrm{C} 100 \mathrm{~g}^{-1}$ soil after 121 days for filter mud, chicken and sheep manures treatments, respectively. This increase of $\mathrm{CO}_{2}-\mathrm{C}$ released reflected the enhancement of soil biological activity.

Also, data in Fig. 2 clearly indicated that inoculation with a mixture of EM inoculants plus filter mud gave the lowest amounts of $\mathrm{CO}_{2}-\mathrm{C}$ released (117.2). The little amount of $\mathrm{CO}_{2}-\mathrm{C}$ released probably due to sharp decline in readily decomposable organic matter and may be attributed to the lowest amount of organic matter in raw material of filter mud contents.

Generally, higher $\mathrm{CO}_{2}-\mathrm{C}$ released from soil treated with mixture of EM plus organic materials, is an indicative of high soil biological activity. The greatest rate of $\mathrm{CO}_{2}-\mathrm{C}$ released was realized in chicken manure with EM treatment. Cumulative $\mathrm{CO}_{2}-\mathrm{C}$ decomposition was obviously increased by increasing the organic materials and bio-fertilizer (EM) application and by the extending duration of incubation. 


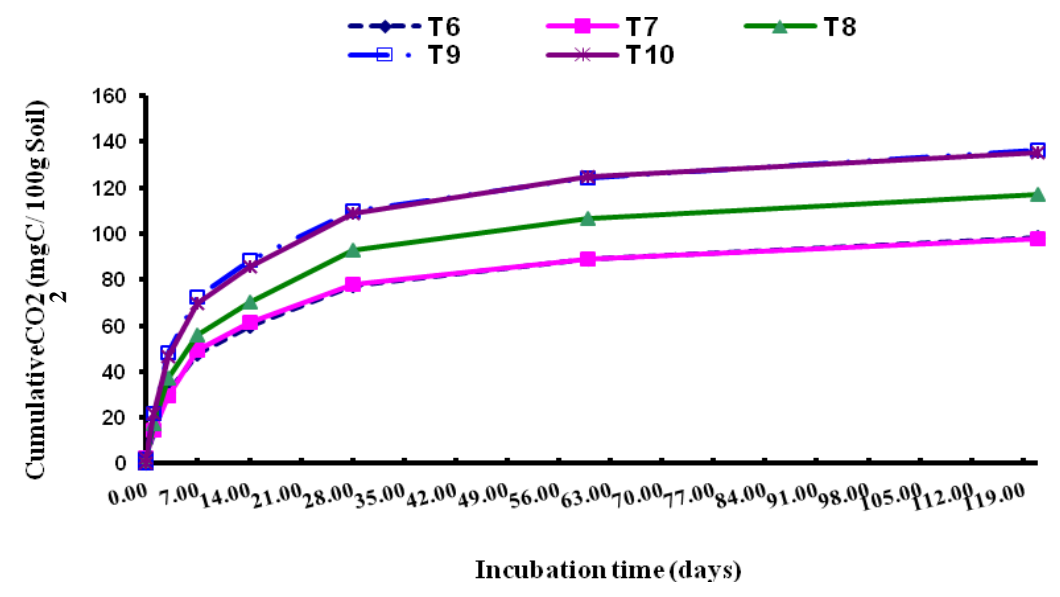

Fig. 2 . Cumulative $\mathrm{CO}_{2}-\mathrm{C}$ released as affected by organic materials plus EM application through incubation time.

These results are in accordance with Fatunbi \& Ncube (2009) who observed that the evolution of $\mathrm{CO}_{2}$ was significantly high with the application of combined EM with organic materials lead to a $24 \%$ high $\mathrm{CO}_{2}$ emission after 56 days of incubation compared to application of EM only.

Over all, organic materials did increase the cumulative $\mathrm{CO}_{2}-\mathrm{C}$ released on all treatments. While the chicken manure treatment showed the greatest effect that prolonged when it combined with EM. It is considered an important source of nutrients usable by microorganisms for improving the cumulative $\mathrm{CO}_{2}-\mathrm{C}$ released. Whenever, EM solution was used with organic materials, it enhanced the microbial population density and hence, production of $\mathrm{CO}_{2}-\mathrm{C}$.

Similar observation was reported by Valarini et al. (2002) who found that the higher percentage increase in cumulative $\mathrm{C}$ released when EM was applied to soil $(44 \%)$ and commercial compost + EM (38\%) compared to Kraal manure + EM $(21 \%)$ and lawn clippings + EM (8\%). This gives an indication of the potentials of EM application to stimulate the mineralization of the more recalcitrant $\mathrm{C}$ in the stabile organic matter pool of the soil and commercial compost.

\section{Effect of organic materials on $\mathrm{CO}_{2}$-C fluxes during incubation time}

Results in Fig. 3 illustrated the effect of organic materials on $\mathrm{CO}_{2}-\mathrm{C}$ fluxes during incubation period. Data showed that the organic materials application increased the rate of $\mathrm{CO}_{2}-\mathrm{C}$ fluxes through incubation time in all treatments compared to control. 
Soil $\mathrm{CO}_{2}-\mathrm{C}$ fluxes was significantly greater in chicken manure addition. The soils receiving chicken manure showed exceptionally higher $\mathrm{CO}_{2}-\mathrm{C}$ fluxes production than those that received sheep manure in all times period.

The peak values of $\mathrm{CO}_{2}-\mathrm{C}$ fluxes were detected at 3 and 7 days of incubation, the mean values of $\mathrm{CO}_{2}-\mathrm{C}$ fluxes were $12.52,11.87$ and $11.61 \mathrm{C} \mathrm{mg} / 100 \mathrm{~g}$ soil at 3 , 7 and 30 days, respectively. Then it gradually decreased as the bio-stabilization process proceeded. This is evidence that the rate of organic matter decomposition was greater in the early stage of chicken manure than in later stages.

This indicates that applied chicken manure had an oppositive effect on soil $\mathrm{CO}_{2}-\mathrm{C}$ fluxes, potentially because of more readily available $\mathrm{C}$ forms and greater amounts of nutrients added in the chicken manure relative to native soil organic matter.

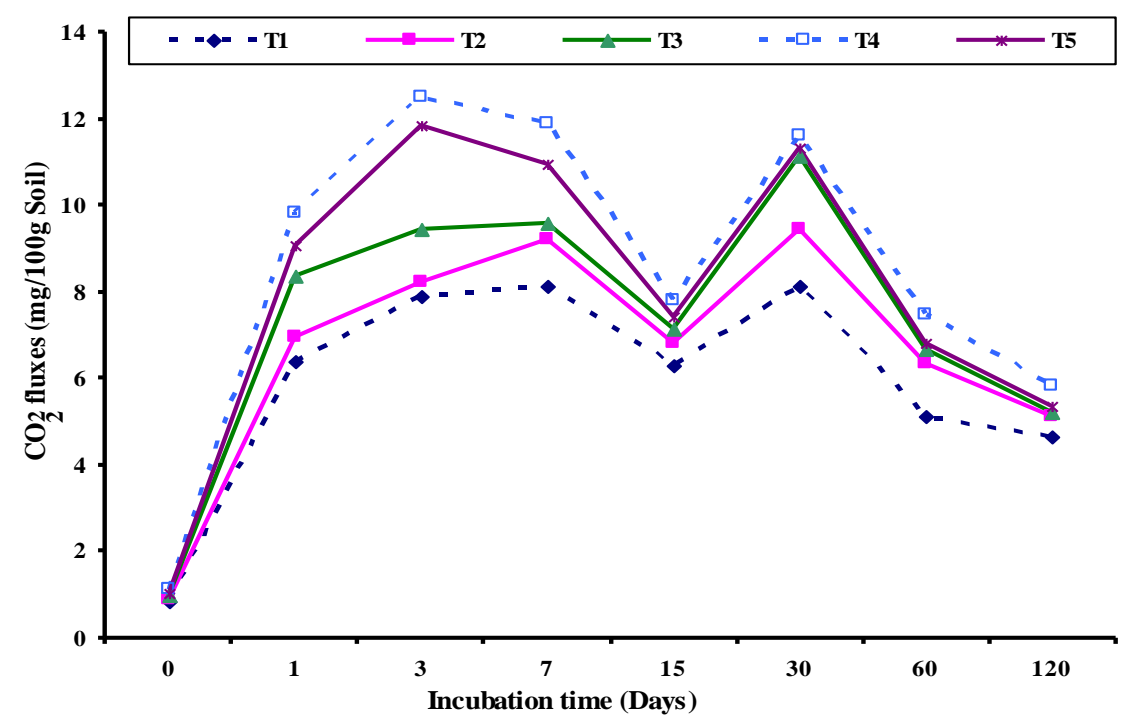

Fig. 3. $\mathrm{CO}_{2}$-C fluxes in relation to organic materials application and incubation time.

The rate of $\mathrm{CO}_{2}-\mathrm{C}$ fluxes was higher after 7 incubation days in soil treated by chicken manure than that in the control treatment and they could be arranged in the following order.

Chicken manure $>$ sheep manure $>$ filter mud $>$ chemical fertilizer $>$ control.

For all treatments, $\mathrm{CO}_{2}-\mathrm{C}$ fluxes sharply declined after 121 incubation days; the least $\mathrm{CO}_{2}-\mathrm{C}$ fluxes $(4.65 \mathrm{C} \mathrm{mg} / 100 \mathrm{~g}$ soil) was observed in case of control treatment at incubation time of 121 days. 
Calderon et al. (2004) observed that addition of manure increased $\mathrm{CO}_{2}-\mathrm{C}$ fluxes of the soils and that the largest difference between manured and control soils occurred after one week since the $\mathrm{CO}_{2}$-C fluxes increased from 42 to more them $400 \%$ in the manured soils.

On the other hand Rudrappa et al. (2006) observed that the cumulative values of evolved $\mathrm{CO}_{2}-\mathrm{C}$ increased rapidly from day 0 to 14 , thereafter the increase was less for the rest of their incubation experiment.

\section{- Effect of organic materials with EM on $\mathrm{CO}_{2}$-C fluxes during incubation time}

Data in Fig. 4 showed that the $\mathrm{CO}_{2}$-C fluxes from soil treated by organic materials with EM were significantly different at all sampling time compared to the control. Data showed that the organic materials with EM additions increased the rate of $\mathrm{CO}_{2}-\mathrm{C}$ fluxes production during incubation time.

The addition of EM with chicken manure had appreciably enhanced the $\mathrm{CO}_{2}$ $\mathrm{C}$ fluxes process during the incubation time particularly in the peak values of the $\mathrm{CO}_{2}$-C fluxes (at 3 and 7 days where the $\mathrm{CO} 2-\mathrm{C}$ fluxes were; 13.14 and $12.22 \mathrm{C}$ $\mathrm{mg} / 100 \mathrm{~g}$ soil, respectively).

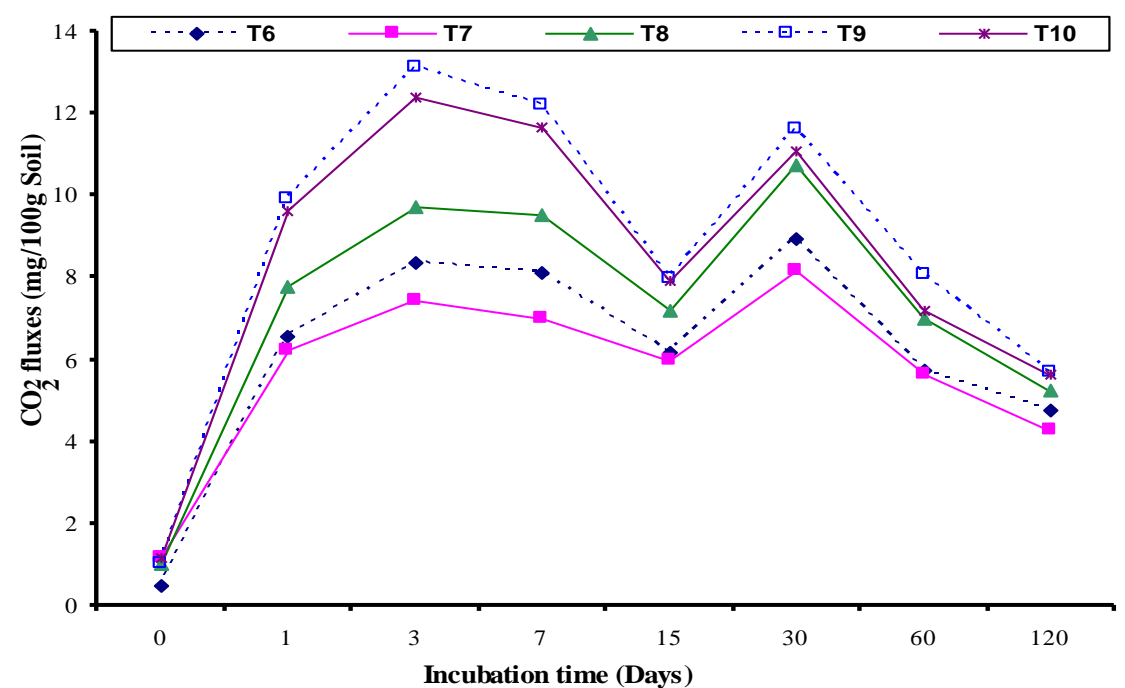

Fig. 4. $\mathrm{CO}_{2}$ - $\mathrm{C}$ fluxes in relation to organic materials and $\mathrm{EM}$ application and incubation time.

This indicates that applied of chicken manure with EM had an oppositive effect on soil $\mathrm{CO}_{2}-\mathrm{C}$ fluxes, potentially because of more readily available $\mathrm{C}$ forms and greater amounts of nutrients added in the chicken manure relative to native soil organic matter. 
Data clearly showed that application of mixed chicken manure with EM gave higher rate of $\mathrm{CO}_{2}-\mathrm{C}$ fluxes than that of sheep manure with EM. Data of $\mathrm{CO}_{2}-\mathrm{C}$ fluxes were almost in harmony with those of total microbial counts. Application of EM in turn improved $\mathrm{CO}_{2}-\mathrm{C}$ efflux in all treatments mainly due to an integration of its beneficial microorganism content.

$\mathrm{CO}_{2}$-C fluxes differed among treatments and could be arranged in descending order of :

Chicken manure $+\mathrm{EM}>$ sheep manure $+\mathrm{EM}>$ filter mud $+\mathrm{EM}>$ chemical fertilizer + EM $>$ EM only.

For all treatments $\mathrm{CO}_{2}-\mathrm{C}$ fluxes sharply declined after 121 incubation days, the least $\mathrm{CO}_{2}-\mathrm{C}$ fluxes $(4.26 \mathrm{C} \mathrm{mg} / 100 \mathrm{~g}$ soil) was observed in case of chemical fertilizer + EM treatment at incubation time of 121 days. Soil microorganisms are mainly represented by ammonificators suggests an intensive organic matter supply due to increasing litter (needles and small branches) and ash element content of soil (Horwath et al., 2002).

Generally, $\mathrm{CO}_{2}-\mathrm{C}$ fluxes gradually increased as the incubation time increased and reached a maximum at although there were substantial fluctuations overall $\mathrm{CO}_{2}-\mathrm{C}$ fluxes then declined to the minimum at the end of incubation time.

These results are in accordance with Fatunbi and Ncube (2009) who observed that application of commercial compost resulted in significantly lower $\mathrm{CO}_{2}-\mathrm{C}$ fluxes at the 2, 7 and 56 days of incubation compared to lawn clippings and kraal manure. Similar trend was observed among the organic materials when EM was applied, although, the $\mathrm{CO}_{2}$-C fluxes were significantly higher at all 2 sampling period with addition of EM compared to organic materials application only.

\section{Soil organic matter changes with incubation time}

Comparing soil analysis after implementation of the incubation experiment, revealed that soil organic matter content was significantly decreased either with organic materials application only or mixed with EM.

Data in Fig. 5 revealed that the individual treatment of organic materials with EM decreased the percentage of $(\mathrm{OM})$ in the soil at end of incubation time. After 121 incubation days, application of organic materials with EM decreased the organic matter content to $0.50 \%$ as average value for all used organic materials.

In this respect, organic materials application with EM stimulated the negative effect on the soil organic matter content which dropped to $0.32 \%$ at the EM treatment. This suggests that organic matter derived from the degraded plankton did not accumulate in the dissolved form but was decomposed to $\mathrm{CO}_{2}$ very quickly.

Egypt. J. Soil Sci. 54, No. 1 (2014) 
Soil organic matter content could be arranged in the following order:

$$
\mathrm{T}_{6}<\mathrm{T}_{1}<\mathrm{T}_{7}<\mathrm{T}_{2}<\mathrm{T}_{8}<\mathrm{T}_{3}<\mathrm{T}_{9}<\mathrm{T}_{4}<\mathrm{T}_{10}<\mathrm{T}_{5}
$$

The superiority of EM in decreasing the percentage of organic matter could be attributed to the microbial biomass contained in EM as well as by its intensity and consequently the total activity of the microorganisms lead to significant increase in the emission of added $\mathrm{C}$.

Although the amount of organic carbon decreased steadily throughout the decomposition process. The decrease in organic carbon although the application of organic materials is excited may be attributed to independent of the added organic materials and such could become slowly available to the microorganisms, special the sheep manures over the raw organic materials.

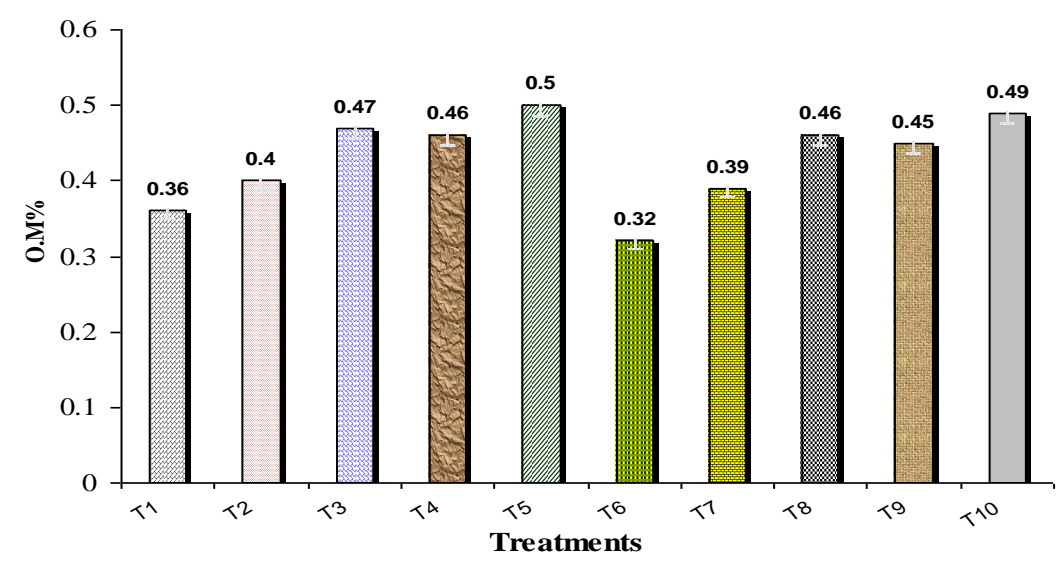

Fig. 5. organic matter content in relation to used organic materials and EM.

\section{References}

Abdel Aal, S.I., Sabbrah, R.E.A., Naser, Y.A. and El-Bassiouny, M. (2002) Impact of rice stubble management on soil microorganisms. 2- microbial activity. Egypt. J. Soil Sci. 42 (4): 725-738.

Abou El-Naga, S.A., Omran, S.M. and Shehata, A.M. (1996) The combined effect of organic manure (FYM) and irrigation regime on the biological activity and nutrients availability in green pepper. Egypt. J. Soil Sci. 38 (1-4):33-45.

Anderson, P.E. (1985) Soil respiration: in methods of soil analysis, part 2. Chemical and microbiological properties. Agronomy Monograph 9: 831-871. 
Araújo, A.S.F., Leite, L.F.C., Santos, V.B. and Carneiro, R.F.V. (2009) Soil microbial activity in conventional and organic agricultural systems. Sustainability 1: 268-276.

Bhaskaran, U.P. and Krishna, D. (2009) Effect of organic farming on soil fertility, yield and quality of crops in the tropics. UC Davis: The Proceedings of the International Plant Nutrition Colloquium XVI.

Branzini, A., Zubillaga, M.S. and Zubillaga, M.M. (2009) Microbial response to the application of amendments in a contaminated soil with trace elements. Am. J. Environ. Sci. 5 (1): 94-98.

Calderon, F.J., McCarty, G.W., van Kessel, J.A.S. and Reeves, J.B. (2004) Carbon and nitrogen dynamics during incubation of manured soil. Soil Sci. Soc. Am. J. 68: 1592-1599.

Dumale, W.A., Miyazaki, T., Nishimura, T. and Katsutoshi, S. (2008) Kinetics of $\mathrm{CO}_{2}$ evolution, soil microbial biomass carbon, and mineral-associated organic carbon of a tropical soil applied with organic matter. NVSU Res. J. XV (1 \& 2): 45-49.

Fatunbi, A.O. and Ncube, L. (2009) Activities of effective microorganism (EM) on the nutrient dynamics of different organic materials applied to soil. Am-Euras. J. Agron. 2 (1): 26-35.

Gopalakrishnan, T.R. (2007) Vegetable Crops. Hort. Sci. Series 4: 32-33.

Gregory, A.S. and Vickers, A.W. (2003) The effects of a composted organic amendment on soil biological properties in a clay soil-forming material used as a landfill restoration cap. Land Contamination \& Reclamation 11 (3): 315-321.

Hanna, Mona, M., Kabeel, S.M.A. and Fayza, M.A. Darwesh (2005) Effect of organic and bio-fertilizers on growth, yield and fruit quality of cucumber (cucumis sativus, L.) grown under clear polyethylene low tunnels. J. Agric. Sci. Mansoura Univ. 30 (5): 2827-2841.

Horwath, W.R., Devevre, O.C., Doane, T.A., Kramer, A.W. and van Kessel, C. (2002) Soil $\mathrm{C}$ sequestration management effects on $\mathrm{N}$ cycling and availability. In: "Agricultural Practices and Policies for Carbon Sequestration in Soil", J.M. Kimble, R. Lal and R.F. Follett (Ed.), Chapter 14, pp. 155-164, Lewis Publishers.

Jackson, M.L. (1973) "Soil Chemical Analysis", Prentice-Hall, Inc. Englewood Cliffs, N.J., New Delhi, India.

Mervat, A., Amara, T. and Dahdoh, M.S.A. (1995) Effect of Inculcation with plant growth promoting rhizobacteria (PGPR) on yield and uptake of nutrients by wheat grown on sandy soil. In the $5^{\text {th }}$ National Congress on Bio Agriculture in Relation to Environment, Cairo, Egypt.

Okur, N., Kayikciolu, H.H., Okur, B. and Del-bacak, S. (2008) Organic amendment based on tobacco waste compost and farmyard manure: Influence on soil biological properties and butter-head lettuce yield. Turk J. Agric. For. 32: 91-99. 
Page, A.L., Miller, R.H. and Keeney, D.R. (1982) "Methods of Soil Analysis. Part 2: Chemical and Microbiological Properties", $2^{\text {nd }}$ ed ., Amer. Soc. Agron. Inc., Soil Sci. Soc. of Am., Madison, Wisconsin, USA.

Rudrappa L., Purakayastha, T.J., Singh, D. and Bhadraray, S. (2006) Long-term manuring and fertilization effects on soil organic carbon pools in a Typic Haplustert of semi-arid sub-tropical India. Soil Tillage and Res. 88: 180-192.

Valarini, P.J., Alvarez, M.C.D., Gasco, J.M., Guerrero, F. and Tokeshi, H. (2002) Integrated evaluation of soil quality after the incorporation of organic matter and microorganism. Brazilian J. of Microorganism 33: 35-40.

(Received 9/12/2012; accepted 29/8/2014) 


\section{النشاط الحيوي للتربة وعلاقتة بإضافة الأسمدة العضوية والحيوية}

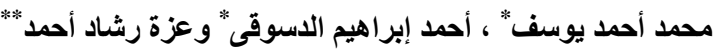

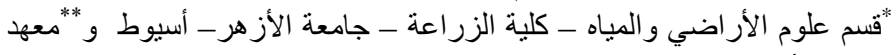

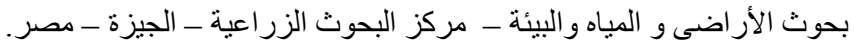

أجريت تجربة تحضين معملية بقسم علوم الأراضى و المياه، كلية زر اعة الأزهر

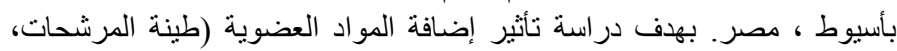

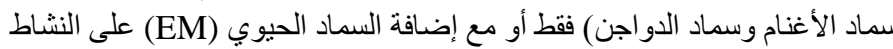

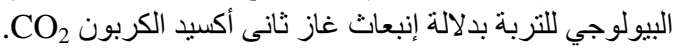

أظهرت النتائج أن مخلوط المو اد العضوية مع (EM) قد أدى إلى زيادة المعدل التر اكمي لغازكربون ثانى أكسيد الكربون CO

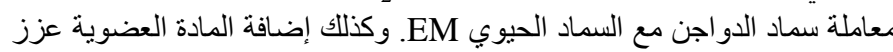
عملية تدفق غاز ثانى أكسيد الكربون خلال فترة التهاد التحضين حيث كان أعلى أعلى قيمة

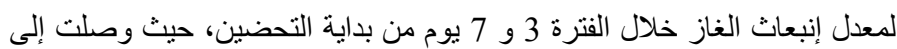

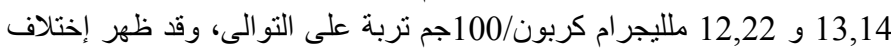

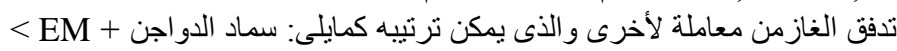

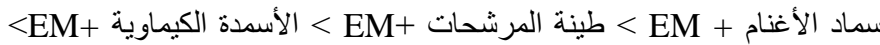
فقط. وفي نهاية فترة التحضين (127 يوماً) كان أكبر تحلل للمادة العضوية فى معاملة السماد الحيوىEM حيث بلغت نسبة المبادة العضوية 0,50٪. 